\title{
Spa Tourism in Twentieth-Century Mexico
}

Mineral springs had been a centerpiece of the experience of foreign visitors to Mexico since the colonial period, when Spanish clerics soaked in the waters of Peñón de los Baños and built baths at Cuincho and San Bartolomé, and natural scientists sought to distill their curative secrets in the field and the laboratory. With the demise of the Spanish empire, travelers made their way more freely to Mexico, often stopping at different mineral and hot springs to test the waters. The war with the United States in the 1840 os brought a few soldiers from the United States to explore the country. After 1860, foreigners rode the rails into Mexico as tourists, searching for novel experiences of food, music, people, crafts, the splendor and bustle of Mexico City, and archaeological sites such as Teotihuacán. ${ }^{1}$ The number of travelers' accounts exploded after 1880, testimony to the new transportation infrastructure, as well as the formation of a leisure class in the United States and Europe. This expansion of tourism included wealthy Mexicans, a tide that also lifted workers and even rural dwellers as the twentieth century progressed. ${ }^{2}$

Waters were a principal tourist attraction, and the economy of leisure was built around them. ${ }^{3}$ Bourgeois residents of European and North American cities had been spending their vacations at mineral water spas and seaside resorts for most of the nineteenth century, and with the opening of Mexico to travel these same groups began to visit springs in Aguascalientes, Tehuacán, Topo Chico, Lake Chapala, and other sites. In chapter 5 we saw that as early as the 1840s urban Mexicans took to country baths on hot spring days, and the bathhouses of Mexico's towns and cities were famous in the second half of the century for their number and quality. Elite Mexican bathers joined foreigners at watering places that were oriented toward a wealthy, cosmopolitan clientele, and rustic mineral springs bathing establishments 
served those with less money who were also caught up in the spa boom. As was the case with bottling businesses, spa tourism also generated conflicts over property and access to mineral waters.

In this chapter I discuss the business of mineral springs bathing between 1920 and 1960. While springs such as Topo Chico and Tehuacán were captured by industrial capital for bottling, many others were developed as tourist bathing destinations. As we have seen, the business model of developing mineral springs for health and therapy was pioneered in the Valley of Mexico by investors close to President Porfirio Díaz, including his doctor, Eduardo Liceaga, and his father in law, Manuel Romero Rubio, who built bathhouses and bottling plants that took advantage of the special properties of the waters of Guadalupe and Peñón de los Baños. With the consolidation of the postrevolutionary state in the 1920 in the hands of northern Mexican generals, the effort to develop Mexico's heterogeneous waters was carried out with even more urgency. Not only did these politicians promote this development with new water laws and government resources, they also invested their own money. The dispossession of mineral springs brought about by government officials benefitted the businesses of those very same people.

Another notable aspect of this period in the history of Mexico's waters is a shift in the rationale of mineral springs bathing away from health and therapy and toward leisure and tourism. By the 1920 s the fascination with mineral water cures was waning among doctors, and the postrevolutionary state was more interested in promoting public health through hygiene and sanitary water infrastructure. The microbial revolution of the nineteenth century propelled biological understandings of disease and wellness to the fore, a position that was consolidated after World War II with the development of antibiotics. While most people retained the idea that mineral spring waters were curative, they came to view waters first and foremost as vacation destinations that contributed to overall well-being through rest, relaxation, and exercise. The therapeutic efficacy of the waters became less important.

Mexico's water history is full of conflict generated by primitive accumulation, policing, and scientific debate. However, the literature on hot springs, almost all of it focused on Europe, scarcely mentions questions of access and property, or struggles among peasants, scientists, clergy, and capital for control of waters. Eric Jennings (2006), however, suggests that these struggles were a central issue for mineral springs. In Mesoamerica, lands and waters were occupied by peasants long before the arrival of Europeans, and although these peasant communities coexisted with and contributed to states for more than a thousand years, they retained some measure of autonomy over local resources. Like that of Topo Chico, the history of the town of Ixtapan de la Sal, in the state of Mexico, provides ample evidence that encroachment by capital and the state on these peasant waters was met with resistance. Unlike Topo Chico, however, in Ixtapan de la Sal that encroachment was eventually limited by this resistance. There, the municipal government of the community fought the alienation of its waters, producing in the 
end a compromise in which capital developed some springs for an elite market, and the municipal government controlled other springs, ensuring that locals and other less wealthy visitors had access to them, and that the town itself benefitted from the business of bathing.

\section{THE SONORENSES AND MINERAL SPRINGS TOURISM}

Agua Caliente hot spring bubbles up on the southern bank of the Tijuana River just a hop, skip, and jump from the United States, across a seasonal trickle of water. The spring is located on what was once the sprawling Rancho de la Tia Juana, a property acquired by Santiago Argüello in the 1840s just before the present-day border was established by the Treaty of Guadalupe Hidalgo. The waters of Agua Caliente were used by locals as medicine, including to ease childbirth. One testimony in 1920 claimed that all "the recent generations and descendants of Don Ignacio Argüello saw the light for the first time in those waters." Inspired by the success of hot spring resorts across the American west in the last decades of the nineteenth century, many speculators had designs on the springs, and in 1899 the Argüello family leased the springs to David Hoffman, who founded the "Agua Caliente Sulphur Company" with a bathhouse and hotel that became well known among tourists to California. Revolutionary conflicts beginning in 1911 kept visitors at home and a major flood in 1916 swept away the buildings. Interest in the property remained, but the Argüellos retained ownership of both the springs and a makeshift changing room located nearby, charging 25 U.S. cents to anyone who wished to use them. In February 1921 a Tijuanense named Rodríguez Galeana, allegedly "conniving" with Americans, filed a claim with the federal government for the springs, arguing that they were national waters because they flowed within the banks of the Tijuana River, and providing as evidence photographs of the 1916 flood that filled the river and covered the springs. 5 The Rodríguez Galeana water grab was rebuffed, but the boom in the business of mineral springs bathing and the 1920 prohibition of alcohol in the United States made the Agua Caliente springs too attractive to leave undeveloped for much longer.

In 1926 three wealthy Americans teamed with Baja California governor Abelardo L. Rodríguez (1923-30) to purchase the springs and a large parcel of land around them from the Argüellos and build a sumptuous spa, hotel, restaurant, and casino complex, which opened its doors in June of 1928. Soon in Agua Caliente there was a swimming pool, private bungalows, a horse racing track, a golf course, and an airport to receive American tourists. Agua Caliente's alcohol, gaming, and nightlife attracted Hollywood's famous and wealthy, as well as political figures and gangland notables such as Lucky Luciano and Al Capone. As governor, Abelardo Rodríguez ensured the success of Agua Caliente by smoothing political wrinkles, facilitating permits, and negotiating with labor organizations. He also invested his own money in the enterprise, and dedicated state resources 


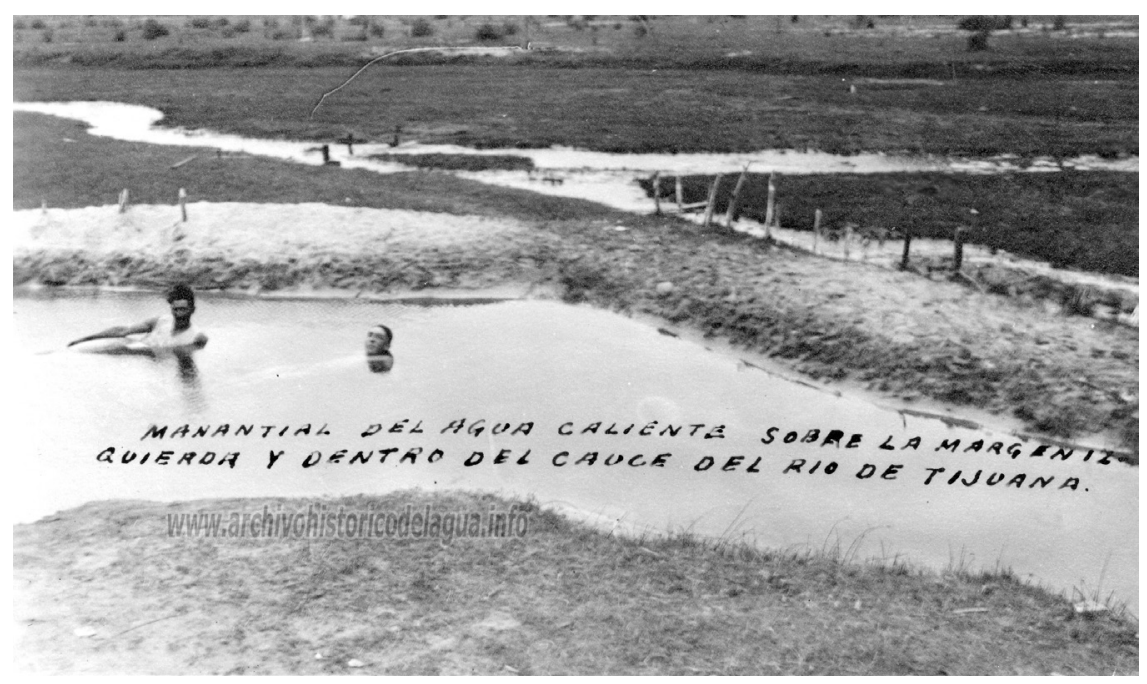

FIGURE 17. "Manantial del Agua Caliente sobre la Margen Izquierda y dentro del Cauce del Río de Tijuana," c. 1920. With permission of the Archivo Histórico del Agua, Mexico City, Mexico. AHA, AS, Caja 723, Exp. 10513.

to the construction of roads, the provision of electricity, policing, and other infrastructures and services.

Rodríguez was a fellow sonorense, revolutionary, and close associate of General Plutarco Elias Calles, who would be president from 1924 to 1928. Rodríguez rose from poverty to become military commander of Baja California in 1921 and also governor of that federal territory from 1923 to 1930. After Calles stepped down from the presidency in 1928, he named a series of his allies to the position, including Rodríguez. Rodríguez brought his experience with hot springs tourism to Mexico City when he was named to take over the presidency after Pascual Ortiz Rubio resigned halfway through his term. Rodríguez was installed as interim president between 1932 and 1934 precisely because of his loyalty to Calles and his followers, and quickly became involved in promoting the ex-president's favorite water tourism spot: Tehuacán, Puebla.

Calles and the political class of Mexico City popularized Tehuacán in the 1920s, and by 1930 the city was bustling with tourists. Bathing in mineral springs and feasting on the regional delicacy mole de cadera became symbolic of the privileges of the new revolutionary elite that Mexican tourists hoped to emulate. With so much money pouring into Tehuacán, it also became known for drinking, gambling, and prostitution, activities that Rodríguez viewed as a normal part of the tourist business. ${ }^{6}$ President Rodríguez further promoted the hot springs resort town by dedicating federal money to building a paved highway from Puebla that reduced 
the time in transit from Mexico City to a mere four hours. It was rumored that both Rodríguez and Calles would stand to personally benefit from the highway, for they had invested their own money in the mineral springs bottling plant built by José María Garci-Crespo and in the luxurious spa hotel that he opened for business in 1934. ${ }^{7}$ This hotel-the Garci-Crespo-eclipsed the recently built Hotel Casino de la Selva in Cuernavaca as the most luxurious watering spot in the Americas.

When Lázaro Cárdenas assumed the presidency in 1934 he stepped back from the tourism development model, devoting state resources instead to productive activities, especially agriculture. Aiming to marginalize Calles and the callistas, and to limit the negative dimensions of tourism development, he outlawed gambling, which was a principal economic interest of that group. Cárdenas closed the Agua Caliente casino complex in 1935, but he actually supported a reformed version of tourism development in the rest of the country. ${ }^{8}$ The Hotel Garci-Crespo thrived without gambling, and, rebaptized as the Hotel Peñafiel in 1948 (a name shared by the brand of mineral waters bottled on the site), continued as the premier vacation spot in Mexico until the development of Acapulco by President Miguel Alemán, who, expanding the sonorense water tourism development model, plowed federal resources into building up that coastal resort for international and national visitors in the late 1940s and 1950s. ${ }^{9}$

In one way or another, all the postrevolutionary presidents and politicians viewed tourism as a desirable development strategy, and many combined their state roles with personal investments. Pascual Ortiz Rubio, who served as secretary of communications and public works in 1920-21, and as president for the two years preceding Abelardo Rodríguez (1930-32), formed the Compañía Impulsora de Acapulco with the goal of building a tourist hotel in that town. In 1935 Ortiz Rubio created Campos Mexicanos de Turismo (CMT), which operated a hotel for U.S. tourists on the Pan-American Highway in Ciudad Valles, San Luis Potosí. A few years later, CMT bought a hot springs bathhouse and hotel in Ixtapan de la Sal, with the plan to turn it into Mexico's premier mineral springs resort and an international tourist destination.

\section{PARTING THE WATERS IN IXTAPAN DE LA SAL: COMMUNITY, CAPITAL, AND THE STATE}

Where politicians and investors eyed profits in mineral springs such as Agua Caliente, Tehuacán, and Ixtapan, locals saw waters that had been used by their families and communities longer than anyone could remember. These were very different understandings of the value of waters, and in the town of Ixtapan de la Sal that difference led to ongoing resistance to the development plans of businessmen and politicians. Ixtapan de la Sal is today a tourist town lodged in the hills that descend south from the Nevado de Toluca volcano in the state of Mexico, about two hours away from Mexico City on the highway. It has scores of hotels that serve 
a wide range of visitors, from wealthy residents of the cities of Toluca, Cuernavaca, and Mexico City to humble campesinos from nearby towns. The landscape surrounding Ixtapan is dotted with country houses for those who can afford them, and growing neighborhoods for those who work in the town's thriving tourist economy. People come to Ixtapan de la Sal to enjoy the sun, the climate and most importantly the waters. There are a multitude of swimming pools in hotels and private houses, the Ixtapan Aquatic Park with its hot springs bathhouse, as well as the hot spring pools of the Municipal Bathhouse in the town center.

None of this existed before 1930. For most of their history, the waters of Ixtapan de la Sal's multiple hot mineral springs were used for producing salt, and although local people almost certainly bathed in the waters, there is no evidence that anyone else did. There were five springs of importance, as well as a handful of tiny ones. San Gaspar, El Bañito, and Santa Catarina springs were located near the town, and the first two were developed early on into rustic pools. Four hundred and fifty meters uphill to the north of town, a pond called Laguna Verde, also fed by hot springs, was used by those bathers who sought a cure for communicable diseases. The El Salitre spring was located half a kilometer south of Ixtapan, downhill toward the town of Tonatico (which has its own springs). Freshwater was taken from a small source near the San Gaspar springs, and, beginning around 1878, an eighty-kilometer-long canal brought freshwater from the slopes of the Nevada de Toluca to the towns in the region. ${ }^{10}$

The saline waters of the mineral springs of Ixtapan left thick deposits of salty soil, and these, as well as the waters themselves, were used to make very pure, white table salt that was sent as tribute to the Aztec kings by the Matlatzincas, and in the colonial period was used for refining silver from the mines of Taxco and Zacualpan to the south. The town had a church, and beginning in 1822 was the seat of municipal government, but had very little freshwater, agriculture, and inhabitants. Salt-making using evaporation ponds-called "Ixtamiles" ("salt-fields" in Nahuatl) - was still an important activity at the end of the nineteenth century, but by 1930 was no longer a profitable business, and only lived on in artisanal fashion to supply local markets based in barter. ${ }^{11}$ While the salt was a key product of the town of Ixtapan, archival records indicate that the conflicts that arose were focused on the use of land for the production of food and livestock. ${ }^{12}$

Between 1870 and 1930 the salty waters of Ixtapan slowly strayed from the orbit of silver mines and were integrated into the tourism economy as the bathing boom that swept Mexico and the world accentuated the value of Ixtapan's heterogeneous waters. In 1877 the Italian immigrant José Nosari identified Ixtapan de la Sal as a good place for a spa that would ride the wave of popularity in mineral springs bathing. He forged a contract with the municipal government for the rights to use the mineral springs for 99 years, paying 100 pesos annually. Nosari sold this contract in 1890 to Santiago Graf, a Swiss immigrant with similar pretensions who managed the hot springs bathing business in Ixtapan de la Sal until revolutionary soldiers 


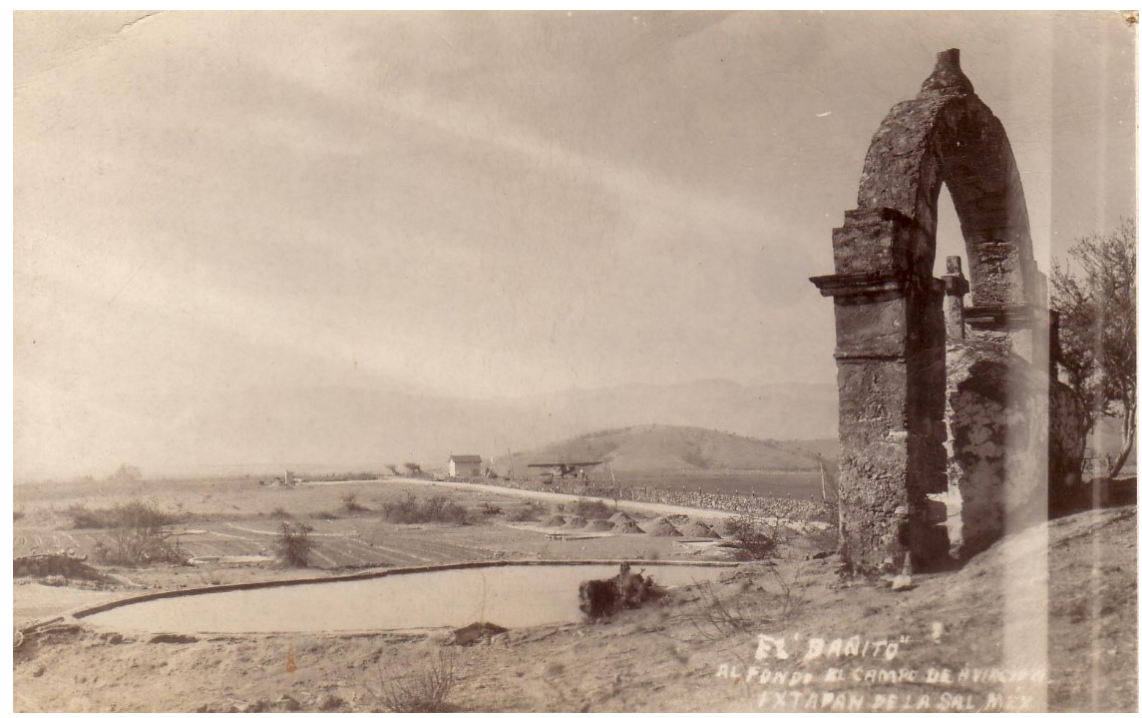

FIGURE 18. "El Bañito: Al Fondo el Campo de Aviación, Ixtapan de la Sal, Mex." Courtesy of Luis René Arizmendi, Ixtapan de la Sal, México. Date unknown. Note the saltworks in the background.

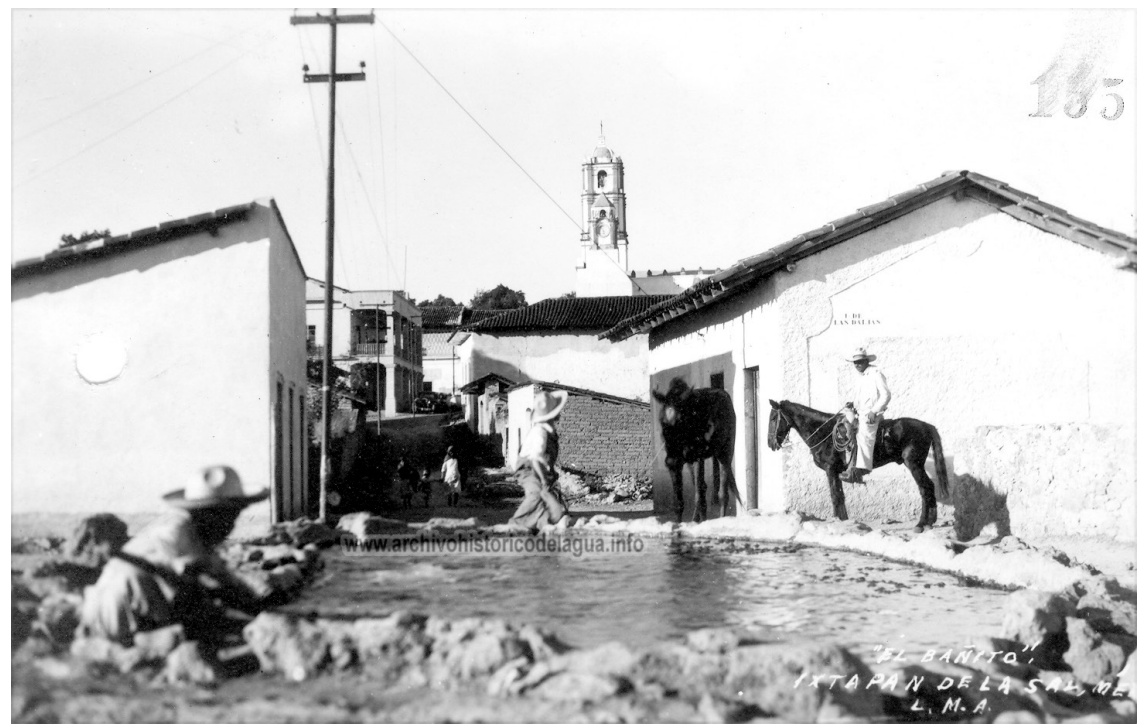

FIgure 19. "El Bañito: Una Pileta Circular." With permission of the Archivo Histórico del Agua, Mexico City, Mexico. AHA, AS, Caja 2058. Exp. 31075, pp. 187-96 (June 2, 1941), "Informe \#79." 
attacked the town, killed five townspeople (the "martyrs of 1912"), and drove the tourists away. Graf abandoned his business between 1912 and 1918 and could not pay the accumulated rent, so the municipal government contracted with a series of three Mexican businessmen between 1919 and 1930 to exploit the hot springs. ${ }^{13}$

José Reynoso, an engineer working in the silver mines of Zacualpan in the 1920s, was impressed by the potential for a bathing business in Ixtapan and had the governor of Mexico State, Coronel Filiberto Gómez, broker a deal with the municipal president José Vergara to acquire the rights to the hot springs, as well as the right to build hotels and bathhouses on municipal land and to use freshwater for these tourism projects. In turn, Reynoso promised to deliver fifteen percent of his profits to the municipality. ${ }^{14}$ The state government spent 4,500 pesos to renovate the pools at the San Gaspar springs, and Reynoso pitched in 1,500 pesos for dressing rooms. Reynoso dedicated much more of his money to buying land and building a 40,00o-peso, 34-room hotel next to the San Gaspar springs, which came to be known as the Hotel-Baths of Ixtapan de la Sal. ${ }^{15}$ State and municipal governments also contributed to developing a much smaller pool at the El Bañito spring that was simply a circular, four-meter-wide hole dug in the earth. The remaining undeveloped springs were also used for drinking and bathing by visitors attracted to Ixtapan by the curative properties of the waters. Reynoso built a rectangular pool at the Santa Catarina spring, with dressing rooms, for the locals. ${ }^{16}$

Reynoso's Hotel-Baths of Ixtapan de la Sal brought an unprecedented influx of visitors to the town, despite the fact that the road was still a dirt track, and his business flourished, serving as many as a hundred people a day by 1941. Other hotels and pensiones for tourists sprouted up during the 1930s, with their guests using the bathing facilities of the Hotel-Baths Ixtapan de la Sal, but almost never the rustic baths at El Bañito and Santa Catarina, which served the poorer, local population. Another entrepreneur, Carlos Rodríguez, arrived in 1933, buying land around the town and investing 100,000 pesos to build the Hotel Casa Blanca. ${ }^{17}$ By 1940 there was another hotel, as well as guesthouses run by American and German immigrants that catered to foreign visitors.

The increasing control over the business of bathing exercised by outsiders was paralleled by a shift in the legal status of Ixtapan's springwaters, from municipal property to federal property. Mexico's 1926 irrigation law declared much of the country's waters to be the property of the nation, and initiated a process of centralization by which local actors were required to either apply for confirmation of existing uses of waters or ask the government for a new concession of those now-national waters. Just as it had in Topo Chico, Nuevo León (chapter 7), this process led to confusion and conflict in Ixtapan de la Sal. Ixtapan's hot springwaters were declared national property by President Pascual Ortiz Rubio in 1932 with the assertion that they flowed into the Río Balsas, but neither the municipal government nor Reynoso himself seemed to have been aware of that change, or the requirement that any existing uses of nationalized waters be registered with the 
secretary of agriculture within the five-year period that followed. ${ }^{18}$ Because of the failure to register these existing uses within five years, the municipality of Ixtapan de la Sal lost rights to the springs, and the contract with Reynoso for those rights was thus null and void. ${ }^{19}$

José Vergara was angry. As municipal president, in 1930 he had signed the Municipality of Ixtapan de la Sal to a 25-year contract with José Reynoso, in which the businessman was given almost total control over the waters of the town, in exchange for fifteen percent of the profits generated by those waters. Now only a year later he was sitting in the office of a notary public in Tenancingo, lodging a claim to the bathhouse and the land where the San Gaspar springs bubbled up. The land and springs were "property and possession" of the people of Ixtapan "since forever," testified residents Juan Hernandez and Onofre Morales. Vergara felt cheated by Reynoso, who had convinced him through "tricks and false promises" that the business would provide a healthy income to the municipality. $\mathrm{He}$ could see the money flowing into Ixtapan de la Sal, with outsiders buying land and building houses and hotels, but only a pittance for the townspeople. It was time to fight.

Source: AHA, AN, Caja 2058, Exp. 31075 (1939); Escrituras de Propiedad (1933); AHA, AS, Caja 2058, Exp. 31075, pp. 151-55, Vergara to Olivier Ortiz.

The problematic legal status of Ixtapan's hot springs soon became apparent in the context of a struggle between national businessmen and local townspeople to control the benefits of bathing tourism in Ixtapan. In 1933, a year after José Vergara signed the contract with Reynoso, the municipal government registered a claim to the land and buildings of the Hotel-Baths Ixtapan de la Sal with a notary public in Tenancinco. When the five-year window for claiming existing water uses with the federal government closed in 1937, the municipal government asked that the secretary of agriculture recognize its right to waters that "have been used since before anyone can remember as public baths." ${ }^{\prime 20}$ In 1938 the municipal government filed concession requests for all the springs in Ixtapan, pointing out to the secretary of agriculture and development (Secretaría de Agricultura y Fomento, or SAF) that since 1932 they were national waters and that neither Reynoso, the municipality, nor anyone else had ever filed a request for their concession. The municipality also tried its luck with other branches of government, filing a claim with the Department of Indigenous Affairs, and even writing to the president. ${ }^{21}$ The secretary of agriculture and development, charged with managing national waters through its General Directorate of Waters (Dirección General de Aguas), ruled in 1939 that both Reynoso and the municipal government had failed to formalize their 
claim to the national springwaters of Ixtapan, and recommended that the townspeople form a cooperative to ask for the concession to supply a modern bathhouse.

The presidency of Lázaro Cárdenas (1934-40) was a period of social reform, marked by the nationalization of the oil industry and large landholdings, the strengthening of labor unions, and the creation of collective farms. The SAF, which controlled the concession of waters, was especially supportive of peasant economic initiatives during this period, and so José Vergara and the townspeople of Ixtapan stepped up the pressure on Reynoso, hiring anarchist lawyer and revolutionary precursor Enrique Flores Magón to represent them. ${ }^{22}$ They formed a cooperative, and filed a new request for water to supply a community bathhouse, and with the profits, to improve the road to Ixtapan, clean up the town for tourism, and build a school, library, and hospital. At the same time, the municipal government withdrew its request for the waters, in the knowledge that Mexican law at the time privileged cooperatives over others requesting to use natural resources. In a strange irony, the municipal government found itself arguing that it had no right to the waters and that the federal government did (thus invalidating the contract), and Reynoso ended up arguing that the water belonged to the municipality (and therefore his contract was valid). As documentation of the multiple legal issues piled up on the desks of the somewhat bewildered and hesitant SAF officials, the townspeople grew increasingly hostile to Reynoso and his Hotel-Baths.

Faced with the knowledge that his contract with the municipal government of Ixtapan de la Sal was invalid, that the springwaters were national property, that the town was determined to recover them, and that the federal government was generally supportive of such actions, Reynoso looked for a way out. He found it in 1940, through an offer by the company Campos Mexicanos de Turismo (CMT) to transfer title of the Hotel-Balneario Ixtapan de la Sal in exchange for 70,00o pesos of stock in the company. ${ }^{23}$ What made the CMT's offer attractive was that its boss was Pascual Ortiz Rubio, ex-president of the Republic (1930-32) and highly connected leader of the growing tourism industry. Ortiz Rubio had clear channels of influence with the federal government, all the way up to the president of Mexico, and on multiple occasions between 1941 and 1945 wrote directly to President Ávila Camacho, or Minister of Agriculture Marte R. Gómez, to advance the interests of the CMT. He was also familiar with Ixtapan de la Sal, for it was he who, as president of the Republic, authorized the nationalization of the town's springwaters in $1932 .{ }^{24}$

Ortiz Rubio created CMT in 1935, pooling money from a group of investors to buy and operate the "Hotel Valles," in Ciudad Valles, San Luis Potosí, a habitual stop for American tourists heading south on the Pan-American Highway. ${ }^{25}$ His development vision included hotels for international tourists and the infrastructure to serve them. CMT's project to develop Ixtapan centered on enlarging the existing hotel from 34 to 100 rooms, expanding the bathhouse on the San Gaspar springs, bringing more potable water to the hotel, and convincing the federal government to pay his company to build a paved highway to connect Ixtapan with 
the urban centers of Toluca, Mexico City, and Cuernavaca and the tourists sites of Metepec and the Grutas of Cacahuamilpa. ${ }^{26}$ CMT bought the Hotel-Baths Ixtapan de la Sal in 1940, and Ortiz Rubio soon presented Ávila Camacho with his proposal to rebuild it as a more modern, international hotel that would look like a "European spa." A chemical analysis of the waters of San Gaspar springs showed them to be rich in sulfates, potassium and sodium chlorides, and useful to treat rheumatism, gout, insomnia, and maladies of the nervous system and skin. ${ }^{27}$ Echoing the nineteenth-century discourse of the water cure, Ortiz Rubio promised "a sanatorium built with all the required and most up-to-date scientific knowledge." ${ }^{28}$ But the focus was on tourism. It was to be, he confided to the president, part of a major development that included the sale of properties for country houses, a highway to Mexico City and Cuernavaca, and a redesigned town layout.

Along with convincing the federal government, Ortiz Rubio and the CMT also had to negotiate with the people of Ixtapan de la Sal, who declared their opposition to the 1930 contract with Reynoso (now with CMT) even before the ink had dried. By 1940 the town organized a cooperative and formulated its own development plan, and Ortiz Rubio, sensing the seriousness of the community's resistance, incorporated some of the elements of this counter plan into a compromise offer. In exchange for disbanding the cooperative, the CMT offered to build a school in the town, and to give a free parcel of land to the municipality for enlarging the bathhouse at San Gaspar. Flores Magón rejected the offer on behalf of the cooperative.

In mid-June 1941, after years of uncertainty, the federal government ruled on the situation. The lawyers of the SAF determined that the Reynoso-municipality contract was valid, but that neither party acted to confirm rights to the water after their nationalization in 1932, and thus neither had rights. Following from this, the municipality had no legal basis by which to pass its rights to the cooperative. The rights to the waters were still the federal government's to award, and President Ávila Camacho ruled, in a Presidential Accord, that the state of affairs would continue, with the CMT enjoying the use of the San Gaspar springs, but under the assumption that it would make a major investment to build a bathhouse and hotel "with all the modern conditions and comforts." ${ }^{29}$ Ávila Camacho reminded Ortiz Rubio of the importance of the "hydrotherapeutic center of Ixtapan de la Sal" for the national strategy of tourist development, and told him that if the CMT could not make such an investment, the water rights would be assigned to someone who could "offer the hope of prosperity both for the locality and for the country's tourist industry." ${ }^{\circ}$ Sensing the legitimacy and power of the position the community had established over the previous years, the president also moved to protect existing free access by locals and "the poor and needy" to the other hot springs in Ixtapan-El Bañito, Santa Catarina, and Laguna Verde.

The Presidential Accord spurred both the CMT and the townspeople to present development plans for Ixtapan that heeded its goals. The CMT, emboldened by the accord, filed its plan along with requests for water from San Gaspar, El Salitre, 
El Ojito, and the freshwater spring. ${ }^{31}$ The cooperative promised much the same: to build the highway, expand the bathhouse, beautify the town for tourists, and build "campgrounds for tourists ... chalets or bungalows ... and fields for tennis, basketball, golf, etc." They would publicize the town internationally in Spanish and English, stressing the "curative properties of the waters," and proceeds from tourism would build schools, a theater, a hospital, a library, and other community services. The government reiterated that the waters would be given in concession to the agent who could raise the capital for investment in a first-rate tourist hotel and bathhouse..$^{32}$ Flores Magón replied that it was unconstitutional to make the concession of the mineral springwaters to the cooperative conditional on its economic capacity to develop them, and maintained that it had legal precedence for using the waters for development. ${ }^{33}$ The state, he argued, had placed its desire for tourist development above the law.

The most important requirement of the Presidential Accord was that whoever controlled the springs would invest large amounts of capital in developing them. The CMT offered ledger sheets and corporate reports as evidence that it could deploy the necessary funds, but the townspeople could only promise the secretary of agriculture that once the water concession was awarded, the cooperative would sell 60,000 pesos of bonds to build the bathhouse. The hotel, they maintained, was not necessary because there were already hotels in Ixtapan. This argument, and the claim that the town could raise the capital, was met with skepticism, and the government rejected the townspeople's petition on the basis that "it did not offer sufficient hope of viability." ${ }^{34}$

Struggling to raise money, the townspeople turned to the next biggest businessman in Ixtapan after the CMT, Carlos Rodríguez, owner of the Hotel Casa Blanca. In 1942 Rodríguez submitted a request for a concession of waters of the Santa Catarina spring, along with a plan to build two swimming pools, a free one that satisfied the Presidential Accord's requirement for access by townspeople and the needy, and another for tourists whom he would charge entry. ${ }^{35} \mathrm{He}$ presented himself as a man of the people who brought prosperity to the town through his hotel, and offered to invest 500,000 additional pesos in rebuilding that hotel and the new bathhouses at the Santa Catarina spring. ${ }^{36}$ The municipality, seeing its chances to control the springs growing slimmer, declared its support for Rodríguez's plan. On the other hand, CMT director Pascual Ortiz Rubio wrote a letter to President Ávila Camacho vehemently protesting the plan for contravening the Presidential Accord, encroaching on the CMT rights established by the 1930 Reynoso-Municipio contract, and promoting unhygienic bathing practices. ${ }^{37}$ Ortiz Rubio hoped to persuade the president to order Secretary of Agriculture Marte R. Gómez, an old agrarista sympathetic to peasant causes, to reject Rodríguez's development plan and his request for the springwaters, but when this pressure went unheeded, the CMT filed an appeal (amparo) in court. ${ }^{38}$ 
Carlos Rodríguez shifted uneasily in his hard wooden chair in the office of the Directorate of Waters, in the Tacubaya neighborhood on the western outskirts of Mexico City. Rodríguez brought his lawyer to the meeting with Olivier Ortiz, manager of the Campos Mexicanos de Turismo, and officials of the Secretaría de Agricultura y Fomento, but it did not make him feel much better about the situation. He was up against Pascual Ortiz Rubio, former president of Mexico, and he felt outgunned in this struggle over the springwaters of Ixtapan. The "junta de avinencia" that he had come to participate in was supposed to reach a compromise settlement, and Rodríguez hoped it would, to avoid further legal costs and delays in the construction of his planned bathhouse in Ixtapan de la Sal. He had followed the letter of the law, including that of the Presidential Accord, but the Campos Mexicanos de Turismo fiercely opposed any competition for the business of bathing in Ixtapan, and word had it that the Ministry of Agriculture only entertained his development plan and request for waters because the secretary himself, Marte R. Gómez, refused to bend under the pressure applied by President Ávila Camacho in support of Ortiz Rubio. As the CMT lawyer spoke, it became increasingly clear that there was no chance they would move forward with his plans. The CMT had already agreed with the government of Mexico State on a plan to develop Ixtapan, and Rodríguez was not part of it. Worse still, Ortiz accused him of trying to dispossess the townspeople of the Santa Catarina spring; and he knew that the CMT employees were going around town undermining his efforts by telling people that they were "selling their birthright for a plate of lentils." Well, they will likely win in the end, he thought, but he was not going to give in at this meeting.

Source: AHA, AN, Caja 1206, Exp. 16354, pp. 178-95, Transcript of the Junta de Avinencia (October 27, 1943).

At the beginning of 1944, the legal status and control over the hot springs of Ixtapan de la Sal was still not defined. Three years earlier President Ávila Camacho had validated the status quo possession and use of the San Gaspar spring by the CMT, but the SAF had never awarded a definite concession of those waters to anyone. In the midst of this uncertainty, the municipal government denounced to Ávila Camacho and Marte R. Gómez the water-grab attempted by CMT and, in an about-face, rejected Rodríguez's request for the Santa Catarina spring. ${ }^{39}$ When the SAF decided to award Rodríguez the concession to the Santa Catarina spring, they made it contingent on the approval of the municipal government, which was not forthcoming. Instead, the municipal government returned to the SAF with its own plan to build a pool at the Santa Catarina spring..$^{\circ}$ In an effort to buy the compliance of the municipal government, the CMT brought its own plan for a municipal 
bathhouse at the Santa Catarina spring, and offered the land, the engineers, and 500 pesos toward its construction. Much like the Presidential Accord reached in 1941, the SAF ruling in 1944 left the situation in Ixtapan unresolved. ${ }^{41}$

A solution, however, was already being negotiated between the municipal government and Arturo San Román, a businessman with deep roots in Ixtapan. San Román enjoyed a certain measure of local trust because his father, Atilano San Román, had arrived in the town in 1890 . More important, however, is that he was also able to muster the capital required to turn Ixtapan into a tourist destination, and his connections to state and federal governments helped him push through decisions. ${ }^{42}$ San Román's vision for Ixtapan went far beyond rebuilding the HotelBalneario, and included the creation of a country club-style development outside of town known as Nueva Ixtapan, with homes built around a new reservoir. To support this project, he planned to ask for concessions not only of the hot springs, but of the freshwater from the canal that supplied the town and its agriculture. ${ }^{43}$

San Román was able to work with the CMT and municipal, state, and federal governments to line up all the pieces of his development plan in the space of a few years. In August of 1944 Ortiz Rubio wrote his friend President Ávila Camacho to ask him to modify his Presidential Accord so that the CMT and San Román could share the project to build a first-rate hotel and balneario, with CMT rebuilding the hotel and San Román investing in the bathhouse and processing the water concession. ${ }^{44}$ In September San Román asked the municipality to sell him lands on which the San Gaspar Balneario was located, and in October the CMT sold San Román its water rights to the San Gaspar, El Ojito, and El Salitre springs. Still, the municipal government and San Román remained at odds over a number of issues, so on December 21, 1944, they presented their arguments for arbitration by the governor of the state of Mexico, Isidro Fabela.

Fabela's ruling was accepted by all parties. They agreed to revise the payment for the land and waters of San Gaspar that had been stipulated in the 1930 pact between Reynoso and the municipal government. San Román was required to pay for and build two balnearios, a low-cost one for locals at the Santa Catarina spring, and a free one at the El Bañito spring for the needy. Income from the Santa Catarina baths would be administered by an independent board, and used to maintain both baths and make other material improvements in the town. The municipality would, furthermore, provide land to San Roman outside of town for a dam to store water from the freshwater canal to be used by the town, and cede to him the property rights of the parcels of land upon which the San Gaspar springs and its hotel and balneario were located. The transactions compelled by the state's arbitration established the definitive rights to land and water that paved the way for capital investment in Ixtapan de la Sal.

Springwaters were a crucial ingredient of the development project in Ixtapan orchestrated by San Román, but so too was freshwater. The nineteenth-century canal that brought water to the fields and homes of Ixtapan was insufficient to supply the growth of San Román's New Ixtapan complex, so he worked with 


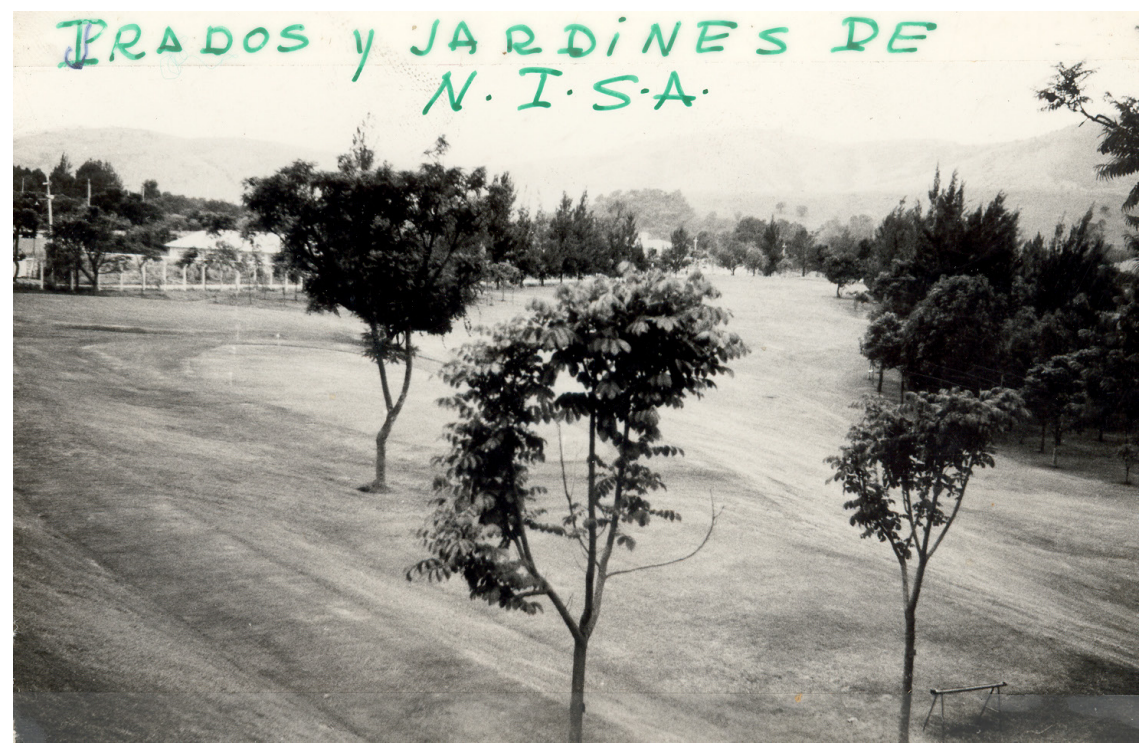

FIGURE 20. View of the Nueva Ixtapan, S.A. housing development, c. 1955. With permission of the Archivo Histórico del Agua, Mexico City, Mexico. AHA, AN, Caja 1204, Exp. 16337.

state and federal governments to improve the infrastructure and increase supply. As early as April of 1944-long before the arbitration ruling was delivered by Governor Fabela-San Román presented the SAF with plans for the construction of hydraulic infrastructure that would convey and store water from the Barranca del Calderón, and convinced Augusto Hinojosa, Mexico State's senator to the National Congress, to order a study of the freshwater available in that barranca and the eighty-kilometer canal. ${ }^{45}$ As soon as the arbitration decision was delivered by Fabela, the SAF sent an engineer to identify water that could be brought to Ixtapan, and once it was determined that there was an available amount of 238 liters per second, San Román filed a request for that amount. He also asked to make temporary use of 1,000 liters per second of the flow of the Barranca to drive electricity-generating equipment. ${ }^{46}$ The rest of the towns along the canal were told that gates would be installed to limit their flows of water, and in 1946 San Román received a fifty-year concession from the SAF to provide potable water to his new tourist development. ${ }^{47}$

The arbitration decision resolved the long struggle between the municipal government and outside developers over the San Gaspar springs, and satisfied the terms of Ávila Camacho's Presidential Accord by channeling capital into the creation of a center of international tourism in Ixtapan de la Sal. The fate of Ixtapan's other springs remained unclear, however. San Román offered to build two bathhouses on the El Bañito and Santa Catarina springs, but Carlos Rodríguez already held the conditional concession of these waters from the SAF. Once San Román 


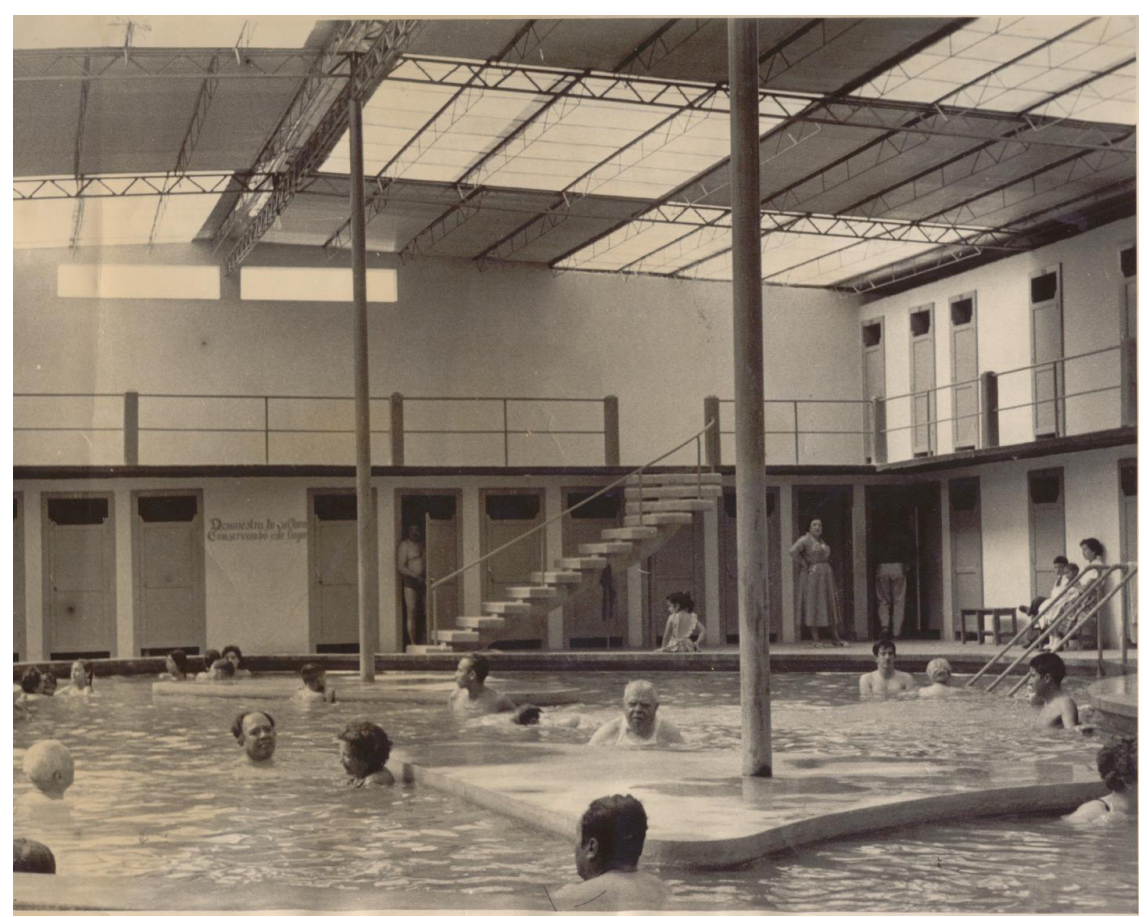

FIGURE 21. Municipal bathhouse, Ixtapan de la Sal, c. 1965. Courtesy of Luis René Arizmendi, Ixtapan de la Sal, Mexico.

took charge of the development of Ixtapan, the SAF attempted to take that concession away, but Rodríguez lodged a legal appeal and Mexico's Supreme Court ruled that the concession was valid even without the permission of the municipal government. ${ }^{48}$

"In reality, the town itself has denied, with weapons drawn, the efforts by Mr. Rodríguez to take possession of the spring. The feelings about this issue are so extreme that I feel Mr. Rodríguez's life would be in danger if he continues any further. . . . The town is not willing, for any reason, to sell or give land to $\mathrm{Mr}$. Rodríguez, and the result is that Mr. Rodríguez has no property on which to build his planned bathhouse."

—Victor Peredo, federal government official, 1953

Source: AHA, AN, Caja 1206, Exp. 16354 (December 4, 1953), Memorandum, Victor Peredo. 
Years of conflict ensued, as Rodríguez attempted to move forward with his plan to build the bathhouses against the sustained opposition of the townspeople and the municipal government. ${ }^{49} \mathrm{He}$ excavated the pools in late 1946, but in March of 1947 construction was interrupted by "various townspeople," and his workers refused to resume their labors. Rodríguez accused José Vergara of scheming with "others from the town interested in obtaining the concession" and petitioned the municipal, state, and federal governments for protection. Witnesses testified that in February of 1950 a group including the municipal president and some police officers stopped the work "at gunpoint."

Rodríguez received no response to these requests for protection, and the works remained abandoned until 1951, when the SAF finally revoked his water concession and building permit..$^{\circ}$ The conflicts between Rodríguez, San Roman, and the townspeople continued to simmer, and 1954 the municipal government passed a resolution to prohibit access by Rodríguez and his workers to the municipal lands on which the springs and bathhouse project were located..$^{51}$ Rodríguez finally gave up, and in the late 1950 s the municipality and townspeople secured the concession of the El Bañito and Santa Catarina springs and built the municipal bathhouse foreseen in the arbitration decision of 1945.

\section{CONCLUSIONS}

The deal reached between San Román and the municipal government of Ixtapan de la Sal enabled politicians and businessmen to develop the town as a tourist destination, and secured some benefits from that development for the townspeople by providing them with a share of the business of bathing through the construction of a municipal bathhouse. In this way, the long struggle of the townspeople to maintain control or access over their local mineral springs was successful. Nevertheless, the townspeople participated in the economic development of Ixtapan in a clearly subaltern position. Once the land and water rights were established, San Román was able to organize, with the support of his allies in the state and federal governments, an elite tourist development scheme that utilized the waters and labor of locals to generate profits for him and his family. ${ }^{52}$ When the canal was finally opened in 1960, all the towns in the region protested the loss of water to Nueva Ixtapan and asked for their previous concessions to be restored. ${ }^{53}$ By this time, however, the spa tourism model promoted by the postrevolutionary government since the 1920 s was a reality, and tourism in Ixtapan sucked the region's land, labor, and waters into its orbit.

The strategy of placing mineral springs tourism at the heart of economic development has been successful across Mexico, and owes its success to the persistence of strong cultural values for virtuous waters. In the town of Oaxtepec, Morelos, for example, an enormous vacation center and water park was built in the 1960 os by the federal government's Mexican Institute of Social Security (IMSS) - the Centro 
Vacacional de Oaxtepec. Oaxtepec's hot springs are only one of many hydraulic features of the Centro Vacacional, which sports an Olympic-size swimming pool, a diving pool with platforms up to ten meters high, various wading pools, sports fields, and numerous restaurants, bars, hotels, and cabins. In 2017 the range of water-based activities expanded even further, as the Six Flags Company opened its "Hurricane Harbor" theme park on this public property. Nearby, in the city of Cuautla, Morelos, the hot springs of "Agua Hedionda" have been developed into a vacation destination, also with a wide range of activities. The state of Hidalgo is famous for its hot springs bathing complexes. And so on, throughout Mexico.

During the twentieth century, hot springs throughout the country were converted into balnearios run by ejidos, town governments, the federal government, and private businesses. The National Water Archives in Mexico (Archivo del Agua) holds hundreds of pages of documents concerning dozens of hot spring during this period, when plans were drawn up to turn them into tourist centers, or perhaps to develop bottling plants using their waters. In each setting a different bargain was struck between local inhabitants and outside businessmen eager to cash in on these virtuous waters. It certainly matters who ends up controlling these waters and the businesses that make use of them, as the sheaves of archival documents chronicling struggles over mineral springs can attest. But regardless of the particular outcome of primitive accumulation, bottling, and spa tourism, the ongoing popularity of these heterogeneous waters is evidence of the deep attraction they continue to exercise. It would be impossible to understand the political ecology of mineral springs without considering the virtues of these waters. 